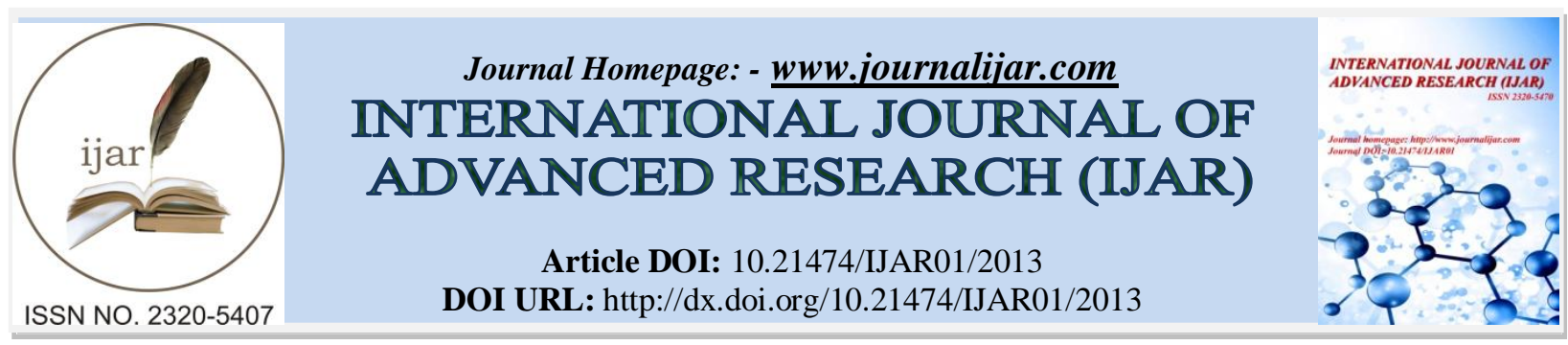

RESEARCH ARTICLE

\title{
THE IMPLEMENTATION OF THE PROPERTY RIGHT IS THE IMPORTANT ATTRIBUTE OF THE PROPERTY RIGHT.
}

D. A. Ciniev.

\section{Manuscript Info \\ Manuscript History \\ Received: 22 September2016 \\ Final Accepted: 6 October 2016 \\ Published: October 2016}

Key words:-
Copy Right, IJAR, 2016,. All rights reserved.

The analysis of foreign and national legislation, doctrinal views of scholars indicate the importance of implementation of the property right as a condition of achieving the owner's aims and objectives at realization of his competences by it.

In substantive legal relationships the subjective civil law is obtained in order that a person could act in regard the property appropriated to him, because "the main way of implementation of the property right is the commission by the owner of actions for possession, utilization and disposition the property independently."I

For the owner the competences are essential means of ensuring the opportunities to act in relation to the appropriated thing exclusively with the will and the interest, therefore the subjective property law transmutes the subject of legal possession to the owner of these means. ${ }^{2}$ Competences of the owner are fulfilled by implementing the specific actions in relation to property, directed on satisfying of the owner's needs or obtaining benefits from its utilization.

Generally accepted that the property right roots in the human nature. The ability to possess the property right is found in the person initially, and its implementation is a satisfaction of the needs of nature. ${ }^{3}$ Therefore, "whichever a history course was, people do it in the following way: everyone pursues his own interests and aims". ${ }^{4}$

In Russian language the words "to carry out, to accomplish, to implement have a meaning to fulfill, to embody in reality, to make, to execute". ${ }^{5}$ "... The implementation of the right is a commission of real, specific actions". 6 "The

${ }^{1}$ Gribanov V. P., "What You Need to Know about the Civil Law." -M.: Knowledge, 1978. -P. 84

2 Chegovadze L. A., "The Structure and the State of Civil Legal Relationship.” -M.: Statut, 2004. -P. 278.

${ }^{3}$ Karahodzhaeva D. M., "The Problems of Development and Improvement of the Legislation on the Ownership of Legal Entities in the Republic of Uzbekistan” Dis.... doctor of legal Sciences. -T: TSJuI, 2008. -P. 44

${ }^{4}$ Marx C., Engels F., Soch. T., 14. -P. 631

${ }^{5}$ Dictionary of the Russian language, Vol. 3. Second ed., corrected and supplement. //Chapters. editor Evgeniev A. P.-M.: Publishing house "Russian language", 1983. -P. 660.

${ }^{6}$ Chegovadze L. A., “The Structure and the State of Civil Legal Relationship.” -M.: Statut, 2004. -P. 165. 
implementation of the right certainly means any use of its contents or, otherwise, the activity corresponding to the content of the right which is expressed in the actual or legal actions".?

In this regard, in order to extract useful properties of a thing the owner realizes his known competences regarding to it. The realization of the subjective real right is enabled both through the commission of own actions, and at the same time by drawing the requirement not to interfere with consumption process, i.e. the prevention and suppression of others actions.

The essence of the competence to own actions implicates that the person is given opportunity of commission of any actions within the bounders of lawful behavior, and also possibility of refusal of their commission. ${ }^{8}$ And moreover, the refusal of implementing the belonging rights does not involve their termination. ${ }^{9}$ The criterion of subjectivity means not only the accessory of the rights to a certain person, but also the dependence on him, first of all in respect of realization. ${ }^{10}$

The realization of opportunities which are enclosed in subjective civil law for the competent is not feasible itself, but, as a result that the right provides him an opportunity to own behavior by means of ensuring a certain behavior on the side of the obliged persons. ${ }^{11}$ Indeed, the possibility of commiting the own actions constitutes an essence of the content of the owner's competences; therefore, the subjective real right induces the obliged person to a certain behavior and, the most important, the owner can realize his competences only when the obliged third parties do not interfere and do not violate the subjective right belonging to him.

In this regard O.S.Ioffe states that the subjective right is the legal instrument for ensuring a certain behavior of the obliged persons stipulating for an authorized person the real, guaranteed by material living conditions of society, possibility of commission of its own actions. ${ }^{12}$

In this regard, implementation of the property right assists to the realization of competences of the owner on possession, utilization and the disposition of property; the requirements to other persons, for a possibility of unimpeded implementation of the property right, and the prevention of encroachments, having included it in case of its violation.

Concentrating on one of the features promoting the implementation of the property right as a realization of competences of the owner, it should be noted that the owner, being the person provided with right for implementation of a triad of powers, can at his discretion and in his own interests fulfill any actions in relation to his property, legality of its actions is characterized emanating from the maintenance of its legal opportunities as an

owner.

At the same time, as Yu.I.Grevtsov notes, "... if the process of implementing the subjective rights is considered as a realization of the opportunities concluded in them, then the implementation of the right also directly impacts on distinction of real, obligational and exclusive legal relationship. ... "legal relationships, their place, role and value are closely connected with implementation of the right". ${ }^{13}$

According to L. A. Chegovadze, "... not only the maintenance of subjective civil law, but also the process of its implementation directly impacts on the development of legal relationship within which the subjective civil law arises and ceases. ${ }^{14}$

In this case, legal regulation is not only the process of granting the participants of the public relations with competences, duties, responsibilities (permissions, prohibitions, authorizations), but also creating the opportunities

${ }^{7}$ Sinayskiy V. I., "Russian Civil Law." -M.: Statut, 2002. -P. 188.

${ }^{8}$ Chegovadze L. A., "The Structure and the State of Civil Legal Relationship." -M.: Statut, 2004. -P. 137.

${ }^{9}$ Article 9 of the Civil Code of the Republic of Uzbekistan.

${ }^{10}$ Matuzov N. I., "Law and Personality"//General theory of law: a Course of lectures. -N. Novgorod, 1993. -P. 242244.

${ }^{11}$ Ioffe O. S., "The Selected Works on Civil Law." -M.: Statut, 2000. -P. 561.

${ }^{12}$ Ioffe O. S., "The Selected Works on Civil Law." -M.: Statut, 2000. -P. 559.

${ }^{13}$ Grevtsov Y. I., "The Problems of the Theory of Legal Relations." - Leningrad: Leningrad state University, 1981. P. 44.

${ }^{14}$ Chegovadze L. A. The Structure and the state of civil legal relationship. -M.: Statut, 2004. -P. 29. 
for realization of these competences, duties, responsibilities, transforming the participants into the subjects of legal relations. ${ }^{15}$ According to S. S. Alekseev, regulatory function of the right is expressed in its impact on the public relations by means of registration of their movement. ${ }^{16}$ And the conclusion that the movement of legal relationship happens only within its design is considered to be important and can be presented as dynamics of its constructive elements. ${ }^{17}$

It is considered that the accessory condition of the absolute real right, allows his owner to realize at discretion the opportunity of property right to implement the competences, utilization and disposition.

In Russian language the word "realization (from Latin word realis - material) means implementation of something planned". ${ }^{18}$ Realization of the norms of law is an embodiment of instructed norms of law in behavior of people. One of the forms of realization the norms of law is utilization - implementation of competences of the person, lawful actions at his own discretion. ${ }^{19}$ Besides, the realization of the right in the most general view is an embodiment in reality social opportunities on the conditions provided by precepts of law and legal relationship and, as a consequence, the person receives various material, spiritual and other types of benefit and satisfies the private interests and individual needs. ${ }^{20}$

"Any subjective right represents social value", but this value can be determined only when it can be realized, i.e. the use the opportunities for satisfying material and cultural needs of the authorized person given by the granted subjective right. ${ }^{21}$

As noted by L. A. Chegovadze the realization of subjective civil law is considered in the form registering the process of achieving the result, which finally represents the actual finding of the concrete benefit, for example, its further consumption. ${ }^{22}$

It should be noted that competency of the person allows him to realize completely at his discretion and in the interests the subjective property right that gives the owner the chance of full economic domination concerning the appropriated thing. At the same time, this circumstance assumes the approach of a duty of the third parties which have to undergo any lawful actions of the owner when using of the property by him. Existence of the restrictions for the third parties, first, allow the competent person most fully and freely exercise the subjective property right, secondly, establish the limits of behavior for the obliged persons towards an appropriated thing, for the purpose of removal the obstacles in its use from the owner.

Therefore, accessory of the absolute property right allows the owner to eliminate all third parties from any invasion both into the process of implementation the competences, and into the sphere of his activity that also obliges them to an appropriate behavior and allows the authorized person to carry out at discretion the competences, which is one more important sign promoting implementation of the property right. This state is reached also by presenting the requirements to these persons, for a possible free use of the property by the owner.

Due to the fact, that the principle of free implementation of the civil rights consists of providing an unlimited initiative of participants of a civil turn. ... citizens and legal entities carry out the civil rights belonging to them at discretion. $^{23}$

As stated by S. S. Alekseev, the accessory right (a state in the right) allows the owner any actions in relation to a thing as to a subject of practical application (consumption) to justify his competences carried out at discretion. ${ }^{24}$

\footnotetext{
${ }^{15}$ Vengerov A. B. Theory of state and law: Textbook for law schools. -M.: New lawyer, 1998. -S. 466.

${ }^{16}$ Alekseev S. S. General theory of law. A course of lectures. In 2 t. T. 1. -M., 1982. -P.193.

${ }^{17}$ Chegovadze L. A. The Structure and the state of civil legal relationship. -M.: Statut, 2004. -P. 58.

${ }^{18}$ Dictionary of the Russian language, Vol. 3. Second ed, corrected and supplement. //Chapters. editor Evgeniev A. P.-M.: Publishing house "Russian language", 1983. -P. 689.

${ }^{19}$ Big law encyclopedic dictionary, //Author and compiler Barikhin B. A.-M.: world Book, 2005. -P. 533

${ }^{20}$ Chegovadze L. A., "The Structure and the State of Civil Legal Relationship." -M.: Statut, 2004. -P. 235.

${ }^{21}$ Gribanov V. P., "What You Need to Know about the Civil Law. -M.: Knowledge, 1978. -P. 22

${ }^{22}$ Chegovadze L. A., "The Structure and the state of civil legal relationship." -M.: Statut, 2004. -P. 235.

${ }^{23}$ Big law encyclopedic dictionary.//Author and compiler Barikhin B. A.-M.: world Book, 2005. -P. 498
} 
It should be noted, that during the Soviet period, some scientists-civilians, opening an essence of implementation of competences of the owner "at discretion and in the own interests" noted that these concepts define the distinction between the right of the owner concerning property and the right of non-owners concerning it. ${ }^{25}$ The academician H.R.Rakhmankulov also claimed that concept of the property right in the Civil Code of the Republic of Uzbekistan is interpreted more widely, than in the Civil Code of UzSSR of 1963. Now, along with the utilization and the discretion it includes the concept about need implementing these competences "at discretion and in the own interests". ${ }^{26}$

So, according to the article 9 (Implementation of the civil rights) of the Civil Code of the Republic of Uzbekistan, citizens and legal entities at discretion dispose the civil rights, including the right to protection. Besides, according to the article 1 (The basic principles of the civil legislation) of the Civil Code, citizens (natural persons) and legal entities get and carry out the civil rights with the will and in the interest. They are free in establishing the rights and duties on the basis of the contract and in definition of any terms of the contract which does not contradict to the current legislation.

Considering the essence of implementing the property right in the interest, it should be noted that the owner realizes the competences for satisfying the own interest, thereby the interest subject is reached. The interest protected by the right makes the purpose and the prerequisite of subjective will which is formed under the influence of interest, becomes stronger in the course of its understanding, acts as conscious interest and means satisfaction. ${ }^{27}$

In real legal relationship the competent authorized person, having property as an object of the civil rights, can satisfy the property (other) interest with the commission of own subject actions necessary for the consumption of useful properties of the benefit which is already created and appropriated to them. So, his subjective civil law is exercised. $^{28}$

Indeed, "The subjective right provides an authorized person with a certain behavior towards the party of the obliged persons, creating opportunity for satisfying the known interests of the authorized person. It also makes an ultimate goal of implementing the right, the will is only one of the conditions to achieve this purpose ...". ${ }^{29}$ Implementation of the right or its refusal mostly depends on the will of the authorized person, ${ }^{30}$ "unlike the right as measures of possible behavior, the duty represents due behavior which is realized depending on a will of an authorized person to carry out the right" ${ }^{131}$. Besides, "The will as the psychological act makes the necessary prerequisite of emergence and eventually implementation of the rights". ${ }^{32}$ And since, the implementation of the civil rights has acts of subjective will of their carriers or the persons representing them in all cases ..., the carried-out legal relations are always the strong-willed relations, irrespective of ways of their establishment. ${ }^{33}$

Introduction to the concept of the property right of implementing the property right "at discretion" and "in the interests", helps to solve two important problems: first, gives the chance to distinguish the rights of the owner and

${ }^{24}$ Alekseev S. S., "Property and Law Current Problems" // Scientific notes: interuniversity collection of scientific papers. Vol. 2. -M.: "Statut"; Ekaterinburg: Institute of private law, 2002. -P. 66.

${ }^{25}$ Venediktov A. V., "State Socialist Property." -M: -L, 1948. -P. 38-41, Ioffe O. S., "The Soviet Civil Law." -M.: Legal.lit, 1967. -S. 361, Y. K. Tolstoy, "The Content of Civil Law Protection of Property Rights in the USSR." Leningrad: Leningrad state University, 1955. -P. 46.

${ }^{26}$ Rahmankulov Kh. R., Comments on part one of the Civil Code of the Republic of Uzbekistan (in Uzbek). -T.: 1997. -S. 313; Rahmankulov Kh. R., a Commentary on part 1 of the Civil Code of the Republic of Uzbekistan. -T: The World of Law and Economy, 1997. -P. 313.

${ }^{27}$ Ioffe O. S., "The Selected Works on Civil Law." -M.: Statut, 2000. -P. 579.

${ }^{28}$ Chegovadze L. A., "The Structure and the State of Civil Legal Relationship." -M.: Statut, 2004. -P. 525.

${ }^{29}$ Ioffe O. S., "The Selected Works on Civil Law." -M.: Statut, 2000. -P. 576.

${ }^{30}$ Khalfina O. R., "General Theory of the Relationship." -M.: Legal. lit., 1974. -P. 240.

${ }^{31}$ Khalfina O. R., "General theory of the relationship." -M.: Legal. lit., 1974. -P. 242.

32 Bratus S. N., "Legal Entity in the Soviet Civil Law. Proceedings of VIJuS of the Ministry of Justice of the USSR.” 1947. Vol. XII. -P. 31

${ }^{33}$ Ioffe O. S., "The Selected Works on Civil Law.” -M.: Statut, 2000. -P. 573. 
non-owners in regards to property; secondly, having proved absoluteness of the relations of the property right, means full freedom to the owner in implementing the rights. ${ }^{34}$

The difference of the property right from others subjective the rights is that the owner carries out the rights at discretion. It means that economic domination of the owner over the property, is based directly on the law, and also exists irrespective of will of other persons, concerning this belonging. In turn, the will of other persons owning property is based not only on the law, but also is connected with the will of the owner ${ }^{35} \mathrm{~L}$. A. Chegovadze also claims that freedom of discretion of the competent subject is limited within a framework only of the objective right (general restriction to abuse this right at its implementation) whereas freedom of the obliged person is defined also by discretion of the competent person. ${ }^{36}$

Meanwhile, when the competent person, having appropriated a benefit, gets the property right to it, in this case the owner requires non-interference of other persons to extraction and consumption of his useful properties. Besides, other persons are obliged not to apply for object of someone else's property as accessory of the property right assumes its alienation from other persons, by establishing a corresponding ban on the encroachment concerning it. Thereby, the owner has the right to demand the termination of any actions violating or interfering to the implementation of his property rights. In case the obliged persons do not adhere to the corresponding instructions, the owner by means of civil ways of protection of the subjective property right eliminates the obstacles which arose while implementing the competences.

As noted by L. A. Chegovadze, obstacles on a way of implementation of the subjective right change a condition of the owner of the right, and his competences to his own actions and competences towards the requirement of others actions (inaction) turn (regenerate) into competences to protection. Thus ... the competence to protection which is a part of elements of subjective civil law in essence is not than other, as manifestation of the same competences to the own actions and competences of the requirement to others actions. But so they are shown not at a stage of normal development of legal relationship and when it regenerates in tort. ${ }^{37}$

The opportunity to the prevent the encroachments, and to protect of the rights of owners in a tort law case, is one more important sign promoting implementation of the property right which possibility of utilization, help the owner of property to provide full and free implementation of his competences.

The planned objectives are achieved by the owner by realizing the competences and if there approaches any obstacle, by means of protection against violations. In the latter case, the obliged person is forced to behavior, necessary for the owner, as accessory of the absolute real right, allows his owner: in case of violation or threat to violation of the belonging right to apply proprietary and civil ways of protection.

Thus violations of the property right represent violations of the general ban which existence oblige all other persons not to break the sphere of others legal accessor ${ }^{38}$, in case of violation the owner of property has a right to protection which is exercised in the course of implementing the property right.

Thereby, in case if obstacles arise in a way of implementation or violation of the property right, the main legal means providing execution by the third parties of the duties is coercion as an implementer of the right for protection which comes only at the specified state.

As L. A. Chegovadze states, implementation of the right is such use of the opportunities of the actual and legal order entering it, which provides that the subject of legal accessory achieves the objects achieved both in the course of normal implementation of the right, and in the course of protection it from violations to which the obliged subject is

\footnotetext{
${ }^{34}$ Ergashev V. Yo., "Theoretical Aspects of Derivation and Cessation of the Rights of Citizens to Private Property" abstract of a thesis to the candidate for Doctor of legal Sciences -T.: TSYuI, 2005. -P.20

${ }^{35}$ Ergashev V. Yo., "Theoretical Aspects of Derivation and Cessation of the Rights of Citizens to Private Property" abstract of a thesis to the candidate for Doctor of legal Sciences -T.: TSYuI, 2005. -P.47

${ }^{36}$ Chegovadze L. A., "The Structure and the State of Civil Legal Relationship." -M.: Statut, 2004. -P. 538.

${ }^{37}$ Chegovadze L. A., "The Structure and the State of Civil Legal Relationship." -M.: Statut, 2004. -P. 134.

${ }^{38}$ Chegovadze L. A., The Structure and the State of Civil Legal Relationship.” -M.: Statut, 2004. -P. 39.
} 
forced to that behavior, which leads to the competent person for implementing the right. ${ }^{39}$ And as V.S.Em claims, the legal duty is the requirement to the subject fixed in rule of law expressing socially caused need of the certain behavior provided with possibility of the state compulsion of the subject to such behavior. ${ }^{40}$ O.R.Khalfina also considers that the subject can be impelled to implementation of the right but only when it is demanded by public interests. ${ }^{41}$ S.F.Kechekyan considers such a need of a certain behavior which is caused by the requirement containing in precepts of law in a duty and is provided with the state coercion. ${ }^{42}$ By N. S. Malein's definition, the duty is a measure of due behavior of the obliged subject necessary for implementing possible behavior of the authorized subject. ${ }^{43}$

In his turn O. S. Ioffe in a civil duty sees the means of regulating the behavior of citizens which is carried out by norms of civil law for ensuring a certain behavior to the person who possesses a duty. This behavior of the carrier of a duty causes opportunity to make the own actions which are means of satisfying the interests of the competent person for the other one. ${ }^{44}$

Implementation of the right in this way, leads to the satisfaction of interests of an authorized person, but thus that authorized person for which protection of interests certain duties are assigned to other person with providing the rights to it, these duties necessary for the execution. Detection of this interest demands that the corresponding rights were considered in connection with the duties assigned on their carriers and also in connection with legal relationship in which they are with the user acting in this legal relationship as the carrier of certain rights and duties. $^{45}$

Meanwhile, the implementation of the property right from the owner of property shouldn't go beyond the restrictions set by acts of the legislation which approach is harmful for people around.

It is considered that the implementation of the property right also establishes limits of freedom for the authorized person realizing the competences belonging to him and, they are subject to restriction with acts of the legislation.

So, according to article 54 of the Constitution of the Republic of Uzbekistan, the usage of property shouldn't cause damage to the ecological environment, violate the rights and interests of the citizens, legal entities and the state. Therefore, the owner when using the property along with implementation of the competences at discretion, takes into account also the conditions setting limits of implementation of the property right such as a property site, its physical and other properties, utilization time, results, etc. ${ }^{46}$

At the same time, when the subject carries out the actions in a condition of accessory of the subjective real right, he is not obliged to coordinate the behavior with someone else, the legislator allocated him with opportunity to be guided only by the discretion and own interests. Thus the owner is not obliged to get approval of the behavior, and all other persons are obliged to undergo this behavior if only it is not harmful for them as the law contains the general restriction on infliction of harm. ${ }^{47}$

Therefore, the implementation of the civil rights can be limited (only on the basis of the law) if that is demanded by the operating law and order. ... the actions of citizens and legal entities which are carried out only with intention to do harm to other person, and also abuse of the right in other forms aren't allowed. ${ }^{48}$

So, according to article 9 (Implementation of the civil rights) of the Civil Code of the Republic of Uzbekistan, ... the implementation of the civil rights shouldn't violate the rights and interests of other persons protected by the law. ...

${ }^{39}$ Chegovadze L. A., "The Structure and the State of Civil Legal Relationship." -M.: Statut, 2004. -P. 139-140.

${ }^{40}$ Em V. S., "Duty Category in the Soviet Civil Law (theory)." Dis. ... candidate. the faculty of law. Sciences. -M., 1981. -P. 39.

${ }^{41}$ Khalfina O. R., "General Theory of the Relationship.” -M.: Legal. lit., 1974. -P. 240.

${ }^{42}$ Kechekjan S. F., "Relations in Soviet Society." -M., 1958. -P. 60.

${ }^{43}$ Malein N. S., "Civil Law and Individual Rights in the USSR." -M.: Legal. lit., 1981. -P. 93.

${ }^{44}$ Ioffe O. S., "The Selected Works on Civil Law." -M.: Statut, 2000. -P. 561.

${ }^{45}$ Ioffe O. S., "The Selected Works on Civil Law." -M.: Statut, 2000. -P. 577-578.

${ }^{46}$ Chegovadze L. A., "The Structure and the State of Civil Legal Relationship." -M.: Statut, 2004. -P. 86-87.

${ }^{47}$ Chegovadze L. A., "The Structure and the State of Civil Legal Relationship." -M.: Statut, 2004. -P. 319.

${ }^{48}$ Big law encyclopedic dictionary.//Author and compiler Barikhin B. A.-M.: world Book, 2005. -P. 498. 
The actions of citizens and legal entities sent on infliction of harm to other person on abuse of the right in other forms, and also on implementation of the right in a contradiction with its appointment aren't allowed.

In that case if, making the actual actions, the owner will not begin to meet all known conditions of realization of the opportunities, it thereby will go beyond the measure of behavior established by the right. The type of behavior thus also changes and it is not an implementation of the right, but abuse of the right (intended or casual infliction of harm). ${ }^{49}$

Thus, on the basis of the stated above it should be noted that realization of competences of the owner on possession, utilization and the disposition of property; requirements to other persons, for a possibility of free implementation of the property right, and also the prevention of encroachments and protection of the rights of owners in case of their violation promote implementation of the property right and serve as the stabilizing factor of a civil turn.

\footnotetext{
${ }^{49}$ Chegovadze L. A., "The Structure and the State of Civil Legal Relationship.” -M.: Statut, 2004. -P. 279.
} 